\title{
Bacterial Community and Its Response to Environmental Factors in River Sediments from Downtown of Tianjin, China
}

\author{
Xuewu Li", Hao Zheng*, Meng Li, Jianjun Huang, Jingmei Sun* \\ School of Environment Science and Engineering, Tianjin University, Tianjin, China
}

Received: 17 July 2020

Accepted: 31 October 2020

\begin{abstract}
Bacterial community in urban river sediments are important participants in the biogeochemical cycles of nutrients. Although the bacterial community in sediments and its response to environmental factors have been studied in individual river or branch, knowledge of that in urban river network is limited. The purpose of this study was to characterize the bacterial community in sediments from urban river network from downtown of Tianjin, China. Bacterial community was investigated using highthroughput sequencing technology and the response of bacterial community to environmental factors was revealed by redundancy analysis (RDA). The predominant bacteria phyla in urban river network were Proteobacteria (39.1\%), Bacteroidetes (13.3\%) and Chloroflexi (10.4\%). The diversity and richness indexes of bacterial community in sediments from low urbanized area were higher than that from high urbanized area. The bacterial community in sediments from different area exhibited significant spatial differences, which was also related to urbanization. Particle size and ion extractable nitrogen (IEF-N) were identified as the main factors influencing the bacterial community in the urban river network. The results indicated that anthropogenic activity played important role in bacterial community and diversity in the urban river network.
\end{abstract}

Keywords: bacterial community, environmental factors, urban river network, anthropogenic activity, high-throughput sequencing

\section{Introduction}

Urban river sediments are widely considered as the pollution sink in urban water environment [1-2]. Pollutants released from sediments into overlying

\#Authors who contributed equally to this work. *e-mail: : JMSun_group@163.com water have become the leading cause of severe aquatic problems (eutrophication, black-odorous phenomenon, etc.) after the management and control of exogenous pollutions [3-4]. Bacterial community in river sediment are the main participants of metabolism [5-6]; it plays an important role in material cycling and energy transport [7-8]. Due to the rapid response to environmental factors, bacterial community may be used as an additional monitoring tool for water quality [9-10]. Studying the bacterial community and its environmental drivers is 
beneficial for pollution evaluation and remediation of urban river sediments.

Several previous researchers have documented the bacterial community and its response to environmental factors in urban river sediments. Ibekwe et al. [8] employed 454 pyrosequencing technology to study the bacterial community in an urban river with various pollutant sources. They revealed that the Proteobacteria, Bacteroidetes, and Acidobacteria were the main phyla, and $\mathrm{NO}_{3}$ was the only major driving environmental factor in sediment. Zhang et al. [11] used 16S rRNA gene-based technology to compare the bacterial community composition in two urban rivers flowing through three typical anthropogenic zones. The results showed the sediments of all sited were dominated by Proteobacteria (41.4-54.4\%), and functional microorganisms for methanogenesis, denitrification and sulphate reduction were respectively significantly related to petroleum, nitrogen and sulfide. Wang et al. [2] also used 16S rRNA gene-based technology to study the diversity and structure of bacterial community in sediment of an urban river. The results suggested that river bacterial community exhibited spatial differences in downtown and the bacterial community composition was mostly affected by $\mathrm{TP}, \mathrm{NO}_{3}^{-}$and metals ( $\mathrm{Zn}, \mathrm{Fe}$ ). Yang et al. [12] employed high-throughput sequencing technology to explore the bacterial community and relevant factors in sediments of an urban river. The results showed that predominant phyla in sediments were mainly affected by sediments total phosphate (TP) and weak acid extractable form nitrogen (WAEF-N). Basically, these studies focused on the bacterial community and its response to environmental factors in sediments of individual river or branch through urban areas.

With the acceleration of urbanization, there have been increasing urban rivers transformed to river network [13]. Bacterial community in sediment may be more related to the degree of urbanization. Influential factors driving the bacterial community structure in river network become more complex due to the morphological adjustments [14-15]. Understanding the bacterial community structure and composition and its interaction with environmental factors in sediments from urban river network is beneficial for ecological city construction and water resources protection. Despite the importance, few articles have reported the bacterial community structure and diversity in sediments from an urban river network [16]. The response of bacterial community to environmental factors is still not clear [6, 17-18].

In this study, 7 representative samples in urban river network from downtown area were collected; their environmental physicochemical factors were measured. This study was aimed to (1) analyze the diversity and structure of bacterial community in urban river sediments from downtown area conducted by high-throughput sequencing technology; (2) reveal the response of bacterial community to multiple environmental factors performed by redundancy analysis (RDA). We attempted to characterize the spatial difference in bacterial community structure of sediments from urban river network and determine the main environmental factors affecting the bacterial community structure differences.

\section{Materials and Methods}

\section{Study Area and Sample Sampling}

Tianjin, the largest port city in the north of China, is located in downstream of Haihe basin. The study area was in the downtown of Tianjin $\left(39^{\circ} 03^{\prime}-39^{\circ} 14^{\prime} \mathrm{N}\right.$, $\left.117^{\circ} 06^{\prime}-117^{\circ} 18^{\prime} \mathrm{E}\right)$. Numerous rivers flowing through this area shaped the urban river network. The flow direction throughout downtown is basically from northwest to southeast as shown in Fig.1. Due to the flat topography, the average annual flow rate of the rivers is slow making pollutants and nutrients easy to be deposited in the sediment. In order to objectively reflect the pollution level and distribution law of river sediments, a total of 7 typical sites were chosen in river network. By referring to the monitoring data of downtown Tianjin (supporting material), site 1, 2, 3 and 4 were chosen from the monitoring sites to reflect the pollution characteristics of sediment from high urbanized area. Site 5, 6 and 7 were chosen from the monitoring sites to reflect the pollution characteristics of sediment from low urbanized area (Fig. 1).

The surface sediments (around 3-10 $\mathrm{cm}$ ) of the seven chosen sampling sites were collected with a Peterson grab on the 4th July, 2019. The water temperature of the sampling sites was around $19 \sim 20^{\circ} \mathrm{C}$. At each sampling site, three parallel samples within $1 \mathrm{~m}^{2}$ were homogenized to be measured. All sediment samples were sealed in plastic bags and then sent to the lab. Physicochemical properties of all samples were determined within $24 \mathrm{~h}$. Some of each sample was kept at $-80^{\circ} \mathrm{C}$ in preparation for DNA extraction and then send to the Beijing Allwegene Technology Co., Ltd (Beijing, China) for MiSeq high-throughput sequencing.

\section{Physicochemical Analysis}

In suit sediment $\mathrm{pH}$ value was measured by the $\mathrm{pH}$ Meter (Ohaus Instrument (Shanghai) Co. Ltd). In suit sediment ORP value was determined by FJA-6 ORP Meter. The total organic carbon (TOC) of the sediment was measured according to the combustion oxidation nondispersive infrared absorption method [19]. The total nitrogen (TN) in the sediment was determined with the Modified Kjeldahl method [20]. Four transferable nitrogen of the sediment (ion extractable nitrogen (IEF-N), strong-oxidant extractable nitrogen (SOEF-N), strong-alkali extractable nitrogen (SAEF-N) and weakacid extractable nitrogen (WAEF-N)) were measured 


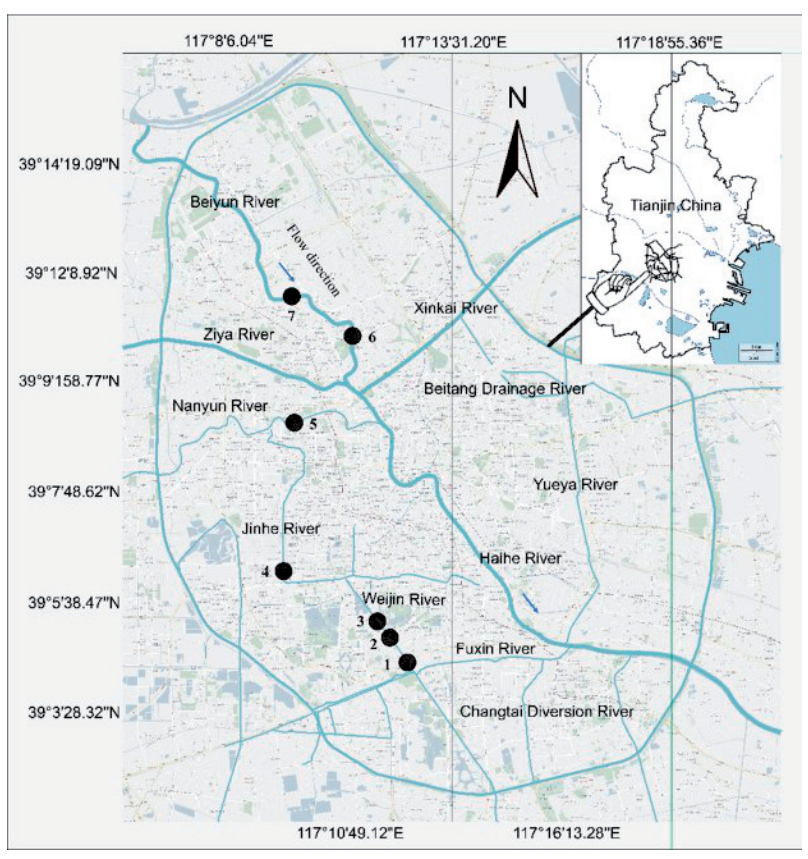

Fig. 1. The locations of the sampling sites.

according to Wang et al. [21]. The total phosphorus (TP), inorganic phosphorus (IP) and organic phosphorus (OP) were measured with the methods according to Zhang et al. [22]. The samples were filtered through a $2 \mathrm{~mm}$ sieve to remove large-grained impurities. The particle size of samples was measured by a LS 13320 laser diffraction particle sizer. The percentage of particle size less than $4 \mu \mathrm{m}$ belonged to powder clay mixture percentage (PCMP), the percentage of particle size between $4 \mu \mathrm{m}$ and $63 \mu \mathrm{m}$ belonged to powder particle percentage (PPP), the percentage of particle size greater than $63 \mu \mathrm{m}$ belonged to sand percentage (SP).

\section{DNA Extraction and MiSeq High-Throughput Sequencing}

All community DNA in $0.3 \mathrm{~g}$ of single sample was extracted by the Fast DNA spin kit for soil (Q-BIO gene, Carlsbad CA) in accordance with the user's guidance. Agarose gel electrophoresis was used to test the DNA quality. The universal 16S rRNA gene primers (338F:5'-ACTCCTACGGGAGGCAGCAG-3' and 806R:5'-GGACTACHVGGGTWTCTAAT-3') were chosen for the amplification, targeting the V3-V4 region of the bacterial 16S rDNA genes. All PCR products were quantified by the QuantiFluor ${ }^{\mathrm{TM}}$-ST blue fluorescence quantification system, and then mixed in proportion to the sequencing volume of each sample.

All PCR products were sequenced by the Illumina Miseq PE300 platform (Illumina, Inc., CA, USA) of Beijing Allwegene Tech Ltd. The raw sequence reads were processed according to the description by Niu et al. (2015) [23]. Mothur software was used to check and remove PCR chimeras to get effective sequences. Then the sequences were clustered into operational taxonomic units (OTUs) with 97\% similarity identity cutoff and the taxonomic classification was measured according to the RDP Classifier.

\section{Data Processing and Analysis}

The bacterial community diversity and richness indices (Shannon index, Chao 1 richness index) of all samples were obtained by Mothur. Bacterial community structure of samples was analyzed on the phylum and genus level. The Bray-Curtis similarity method of PAST 3.0 was used for the clustering analysis of bacterial community at the phylum level [24]. Redundancy analysis (RDA) was conducted to reveal the connection in the environmental factors and bacterial community structure by CANOCO for Windows 5.0. SPSS 22.0 was adopted for the correlation analysis in the bacterial community and environmental factors. Significant differences were accepted at $\mathrm{p}<0.05$. Statistical processing was accomplished with Microsoft Excel 2013.

\section{Results and Discussion}

\section{Physicochemical Properties of the Sediments}

The physicochemical properties of sediments in 7 sampling sites were shown in Table 1. The PCMP ranged from $55.60 \%$ to $88.40 \%$, being the maximum value in sample 2 and the minimum value in sample 7. The PPP ranged from $7.60 \%$ to $18.70 \%$, being the maximum in sample 7 and the minimum in sample 2. The SP ranged from $4.00 \%$ to $25.70 \%$, being the maximum in sample 7 and the minimum in sample 2 . The distribution of SP showed the similar trend with PPP. Basically, the sediments in high urbanized area (sample 1, 2, 3 and 4 with average PCMP value $79.40 \%$ ) had more fine particles than low urbanized area (sample 5,6 and 7 with average PCMP value $71.70 \%$ ). The $\mathrm{pH}$ value of the sediments was around 7.0. The ORP value differed dramatically across different sediment samples. TOC, TN and TP varied obviously across different sediment samples, being the maximum in sample 1 and the minimum in sample 7. Basically, the pollutant and nutrient concentration in sediments from high urbanized area was higher than that from low urbanized area. The spatial characteristics of the various forms of nitrogen and phosphorus, such as IEF-N, SOEF-N, SAEF-N, WAEF-N, OP and IP, were same as the TOC, TN and TP. In high urbanized area, there were more vehicles discharging a large amount of vehicle emission. Organic pollutants in vehicle emission would be absorbed in particles and then flowed into the river along with runoff and finally accumulated in sediment. Besides, the site 1, 2, 3 and 4 were located in an area surrounded by universities and residential belt with high population density, and the discharge of sewage might also lead to the high pollutant and nutrient concentration. 
Table 1. Physicochemical factors in sediments of 7 sampling sites.

\begin{tabular}{|c|c|c|c|c|c|c|c|}
\hline Sampling site & 1 & 2 & 3 & 4 & 5 & 6 & 7 \\
\hline PCMP (\%) & 78.50 & 88.40 & 74.20 & 76.40 & 83.80 & 75.80 & 55.60 \\
\hline PPP (\%) & 11.50 & 7.60 & 14.80 & 14.00 & 9.40 & 12.40 & 18.70 \\
\hline SP (\%) & 10.00 & 4.00 & 11.00 & 9.60 & 6.80 & 11.80 & 25.70 \\
\hline pH & 6.93 & 7.06 & 6.95 & 6.95 & 6.67 & 7.01 & 7.11 \\
\hline ORP (mV) & 207.90 & 163.30 & -71.90 & 218.30 & -43.20 & 38.20 & 44.70 \\
\hline TOC (\%) & 8.19 & 6.15 & 4.34 & 2.62 & 4.04 & 3.15 & 1.53 \\
\hline TP $(\mathrm{mg} / \mathrm{g})$ & 3.88 & 1.87 & 2.50 & 2.65 & 1.91 & 1.43 & 1.26 \\
\hline OP $(\mathrm{mg} / \mathrm{g})$ & 1.0155 & 0.4671 & 0.5289 & 0.6488 & 0.1802 & 0.2907 & 0.0939 \\
\hline IP $(\mathrm{mg} / \mathrm{g})$ & 2.3419 & 1.6547 & 1.9361 & 1.8848 & 1.2064 & 1.3276 & 0.9622 \\
\hline TN $(\mathrm{mg} / \mathrm{g})$ & 4.21 & 1.96 & 2.10 & 2.71 & 0.97 & 2.77 & 0.91 \\
\hline SOEF-N (mg/g) & 0.9886 & 0.4340 & 0.6074 & 0.8080 & 0.2828 & 0.7155 & 0.2262 \\
\hline WAEF-N (mg/g) & 0.1897 & 0.0802 & 0.1523 & 0.0916 & 0.0639 & 0.1083 & 0.0480 \\
\hline SAEF-N (mg/g) & 0.1180 & 0.0566 & 0.0755 & 0.0685 & 0.0370 & 0.0724 & 0.0307 \\
\hline IEF-N (mg/g) & 0.0868 & 0.0151 & 0.0199 & 0.0167 & 0.0159 & 0.0433 & 0.0219 \\
\hline
\end{tabular}

Diversity and Richness of Bacterial Community

High-throughput sequencing technology of $16 \mathrm{~S}$ rRNA was performed and the diversity and richness indexes of bacterial community was shown in Table 2 . There was a total of 12973 OTUs of all sediment samples. The OUT number of a single sample ranged from 1321 to 2109 and was ordered as $5>7>6>3>2>1>4$. The Shannon index can provide information about the number of species and the distribution of abundance of all species; it was between 8.30 and 9.54, being the maximum value in sample 5 and the minimum value in sample 4. The Chao 1 richness index was ranged from 1567.51 to 2359.08 , being the maximum in sample 7 and the minimum in sample 4. Basically, the diversity and richness indexes of bacterial community in sediments from low urbanized area (sample 5, 6 and 7 with average OTUs 2087, Shannon 9.43, and Chao 1 index 2336.44) was higher than that from high urbanized area (sample 1, 2, 3 and 4 with average OTUs 1678, Shannon 8.62, and Chao 1 index 1953.76). Zhang et al. [16] obtained a total of 4311 OTUs from all sites by Illumina MiSeq sequencing. This study obtained a total of 12973 OTUs and a high diversity index making sure that the bacterial community diversity and composition could be accurately analyzed.

The difference of bacterial community diversity in sediments is probably due to the anthropogenic activities. Excessive accumulation of anthropogenic nutrients or contaminants in urban river sediments would be harmful for the metabolism of bacterial communities and further impact upon the diversity [25-26]. Vehicle emission was a significant source of polycyclic aromatic hydrocarbons in Tianjin area [27]. Site 1, 2, 3 and 4 were located in a high urbanized area with large amounts of vehicles, much more organic pollutant from vehicle emission accumulated in the sediment due to a series of natural process. Thus, the bacterial community diversity in sediment from high

Table 2. The richness and diversity indices of 7 sampling sites with $97 \%$ similarity identity.

\begin{tabular}{|c|c|c|c|c|c|}
\hline Sampling site & OTU $_{\mathrm{S}}$ & Goods coverage & Observed species & Shannon & Chao 1 \\
\hline 1 & 1655.00 & 0.966 & 1602.10 & 8.96 & 2032.61 \\
\hline 2 & 1834.00 & 0.963 & 1498.60 & 8.38 & 2000.37 \\
\hline 3 & 1901.00 & 0.960 & 1686.00 & 8.85 & 2214.54 \\
\hline 4 & 1321.00 & 0.973 & 1204.60 & 8.30 & 1567.51 \\
\hline 5 & 2109.00 & 0.964 & 1881.30 & 9.54 & 2293.19 \\
\hline 6 & 2048.00 & 0.960 & 1901.10 & 9.36 & 2357.06 \\
\hline 7 & 2105.00 & 0.960 & 1929.60 & 9.38 & 2359.08 \\
\hline
\end{tabular}




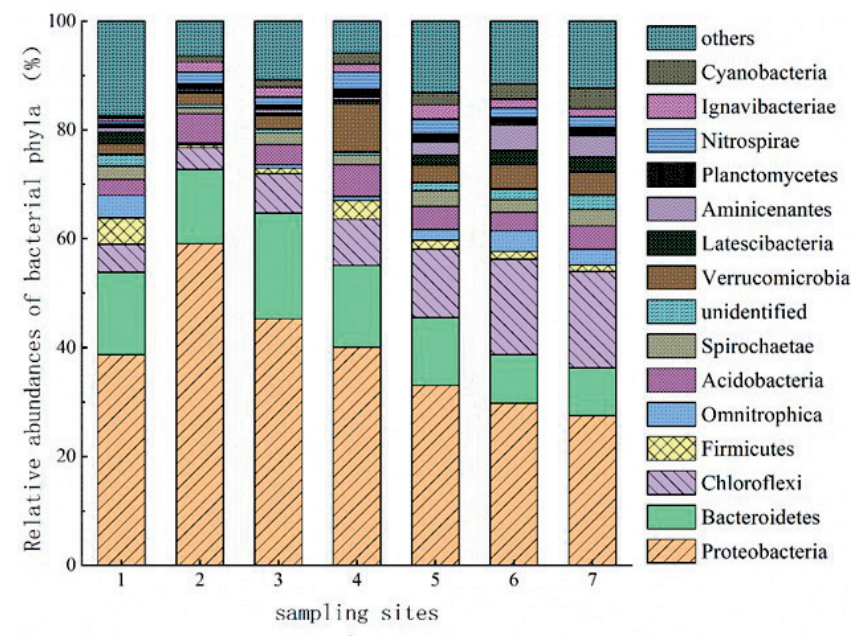

a)

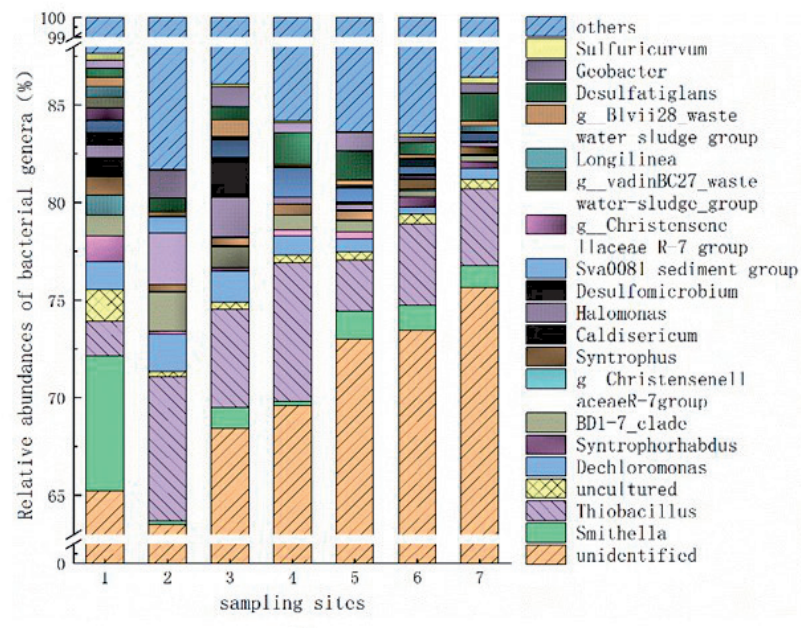

b)

Fig. 2. The relative abundances of different phyla a) and genera b) in each sediment samples.

urbanized area suffered more impact from organic pollutant than that from low urbanized area.

\section{Bacterial Community and Its Relation with Environmental Factors}

\section{Taxonomic Composition and Spatial Variation of Bacterial Community}

To better understand the bacterial community structure of 7 sediment samples, taxonomic composition of bacterial communities at the phylum and genus level was showed in Fig. 2. The relative abundance and composition of the top 15 phyla were shown in Fig. 2a). Proteobacteria (an average of $39.1 \%$ ) was the most abundant phylum among all sampling sites, followed by Bacteroidetes (an average of 13.3\%), Chloroflexi (an average of 10.4\%), Acidobacteria (an average of $4.3 \%$ ), and Verrucomicrobia (an average of $3.9 \%$ ). Besides the large amounts of unidentified bacteria, the top 5 abundant genera were Thiobacillus (an average of 4.6\%), Smithella (an average of 1.7\%), Dechloromonas (an average of 1.1\%), Desulfatiglans (an average of $1.0 \%$ ), and Halomonas (an average of $0.9 \%$ ) (Fig. 2b). Basically, bacterial community populations were dominated by Proteobacteria, Bacteroidetes and Chloroflexi, which was consistent with the recent research in urban river network [16].

Regarding the spatial distribution of the bacterial community, all sampling sites based on bacterial phyla were clustered into two distinct groups (Fig. 3). Sampling sites in Group I were located in low urbanized area of downtown surrounded mainly by the farmland. Sampling sites in Group II were located in high urbanized area surrounded by many housing estates and shopping centers with higher population density. It was obviously different between two groups, indicating that the degree of anthropogenic activities had great influence on the bacterial community composition [11].
Sediment samples in Group II had more fine particles and higher pollutant and nutrient concentration than that in Group I (Table 1). It is speculated that the particle size and pollutant and nutrient concentration may be the driving factors shaping the variation of bacterial community structure.

With respect to the top 5 abundant phyla, Proteobacteria ranked first in two groups. The relative abundance of Chloroflexi and Verrucomicrobia were higher in Group I, while Bacteroidetes and Acidobacteria were higher in Group II. Anaerolineaceae was the dominant family among Chloroflexi and its variation in relative abundance was the main reason causing variation of Chloroflexi. Higher relative abundance of Anaerolineaceae which uses simple carbon for anaerobic metabolism means more low molecule organic matter content in sediments of Group I [28]. More Acidobacteria which was frequently associated with the biodegradation of organic pollutants [29-30] was found in Group II, indicating that more organic contaminants participated in sediments of Group II. Regarding phyla with relative low abundance, higher relative abundance of Nitrospira was found in Group I. Nitrospirae was regarded as the essential participant in the nitrogen cycling [31-32]. Lower relative abundance of Nitrospirae in Group II might due to the excessive input of nitrate which inhibits nitrifying microorganisms' activity. Besides, the relative abundance of Firmicutes in Group II (an average of $2.5 \%$ ) was almost two times higher than that in Group I (an average of 1.3\%) which showed obvious response of Firmicutes to environmental gradient. In this study, the abundance difference of class clostridium (an average of $2.2 \%$ in Group II, an average of $1.2 \%$ in Group I) accounted for the abundance difference of Firmicutes. Class clostridium is the typical anaerobic fermentation bacteria. It indicated that organic matter in sediments of Group II was more susceptible to anaerobic 


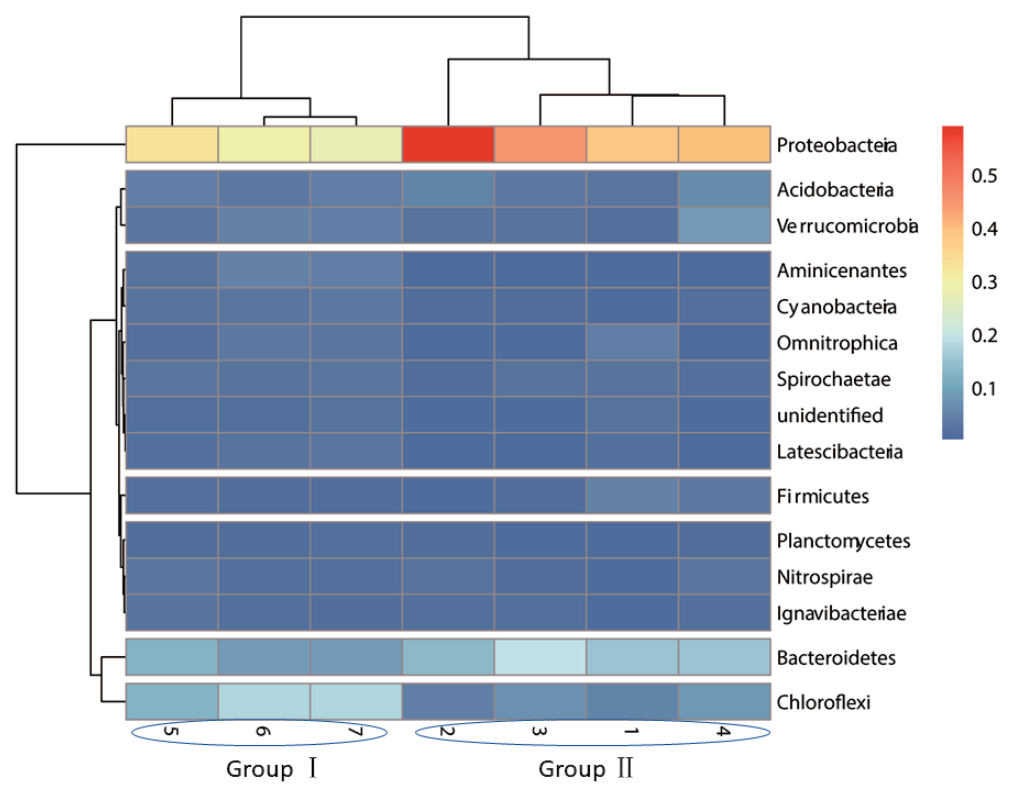

Fig. 3. Cluster analysis of the sampling sites based on bacterial phyla.

fermentation. Due to the different impact from anthropogenic activity, bacterial community structure and composition were obviously distinct between two groups in the urban river network in downtown.

\section{Correlation Analysis of Bacterial Community and Environmental Factors}

The relationship between the bacterial community and the environmental physicochemical factors of each sediment samples was analyzed by RDA on the phylum and genus level (Fig. 4). At the phylum level (Fig. 4a), it could be seen that the characteristic value on the horizontal axis was 0.8469 , accounting for $84.69 \%$ of the information; the characteristic value on the longitudinal axis was 0.0828 , accounting for $8.28 \%$ of the information. According to the relationship between bacterial phyla and environmental factors, particle size and nutrient factors had longer lines on the horizontal and longitudinal axes, indicating that particle size and nutrient factors had larger impacts on the overall bacterial community.

At the genus level (Fig. 4b), it could be seen that the characteristic value on the horizontal axis was a)

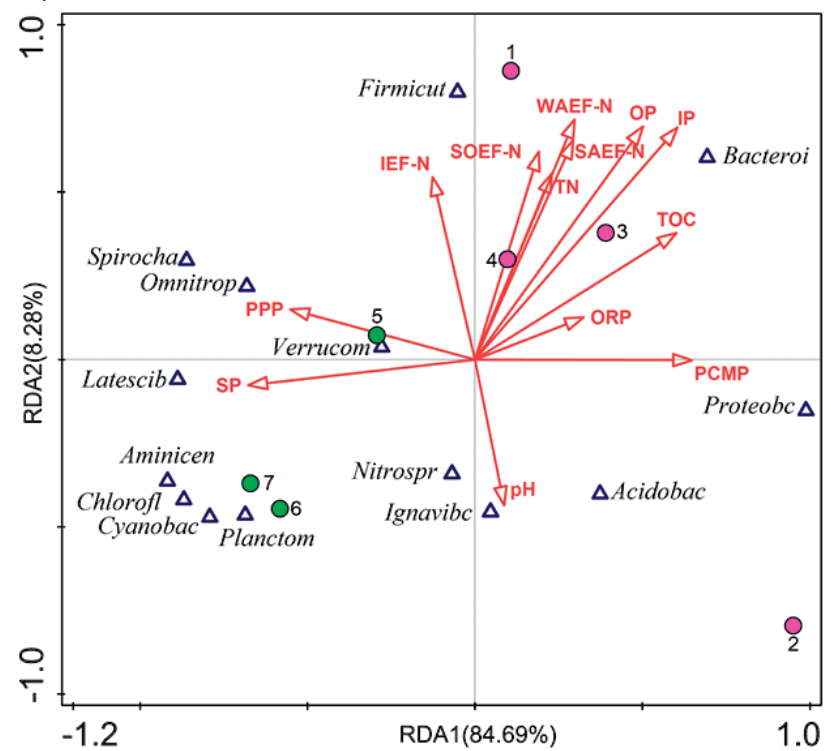

b)

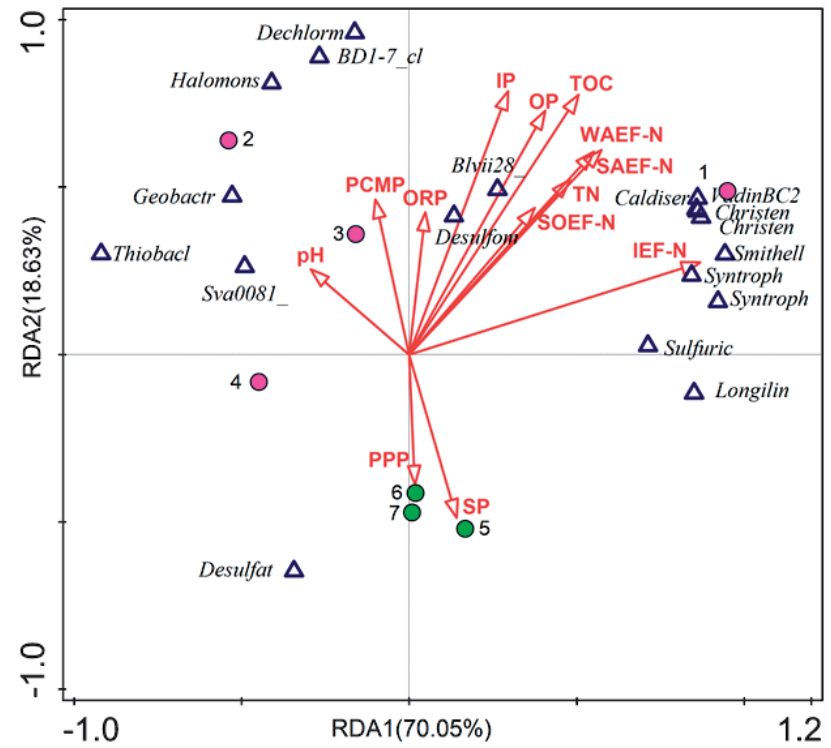

Fig. 4. Redundancy analysis (RDA) of bacterial community (phyla a); genera b)) and environmental factors in sediments of 7 sampling sites. 
0.7005 , accounting for $70.05 \%$ of the information; the characteristic value of the longitudinal axis was 0.1863 , accounting for $18.63 \%$ of the information. According to the relationship between bacterial genera and environmental factors, particle size and nutrient factors had larger impact on overall bacterial community, which was consistent with the phylum level. Sample 5, 6 and 7 were more affected by SP and PPP, while other samples were more affected by PCMP, and nutrient factors. Most pollutant and nutrient factors (except IEF-N) showed positive correlation with PCMP (Fig. 4). This was probably because of the large specific surface area of PCMP which was conducive to adsorption of pollutants and nutrients, indicating the great impact particle size had on bacterial community structure. As the easily released exchangeable nitrogen, IEF-N showed little correlation with particle size, indicating IEF-N might act as another separate driving environmental factor. Bacterial community living in or on the sediments at the bottom of the water system are influenced by various environmental factors [5, 33]. Fan et al. [34] found that water temperature, $\mathrm{pH}$ and nutrients content were the main factors influencing the bacterial community in river sediments. Yang et al. [12] reported that differences in bacterial community of urban river sediments were mainly caused by TOC, TP, WAEF-N, IEF-N and cation exchange capacity, several abundant bacterial phyla were closely related to these factors. Wang et al. [35] concluded that the median grain size and DO were the most significant factors influencing the bacterial diversity and abundance in sediments. The results of the present study indicated that particle

a)

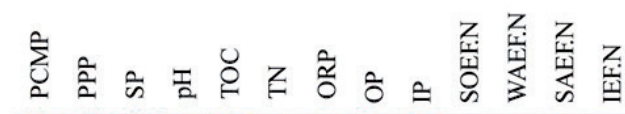
(DQQ $D D D Q D D \triangle D \triangle$ Proteobacteria Q 400 D D 1 (1) DD D ' Bacteroidetes QDO 000000004 chloroflexi

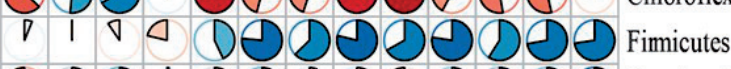

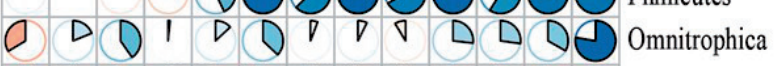
$\triangle \triangleleft \triangle D Q O D \triangle \triangle Q O Q O$ Acidobacteria

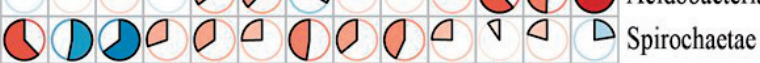

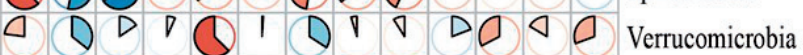

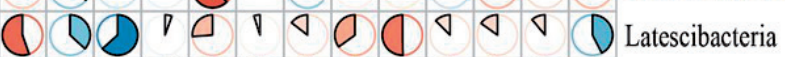
(1)DDOOOOOOOO I Aminicenantes ( D D' OQ OOOOOO Planctomycetes D 140001 OOOOOO Nitrospirae DQ OOO OOOOOOOO Ignavibacteriae ODO DOOO COOOOO Cyanobacteria

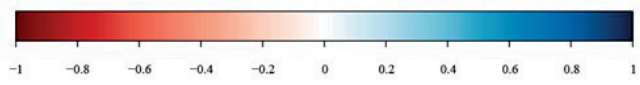

size and IEF-N were the main factors influencing the bacterial community structure in sediments from urban river network.

To further reveal the relationship between the bacterial community composition and environmental factors, correlation analysis of bacterial phyla and genera with abundant relative abundance and environmental factors was conducted as shown in Fig. 5. The results indicated that most phyla were significantly correlated with particle size and nutrient factors $(\mathrm{P}<0.05)$ (Fig.5a). The relative abundance of Proteobacteria was significantly positively related to nutrient factors $(\mathrm{P}<0.05)$, and negatively correlated with PPP and SP $(\mathrm{P}<0.05)$. The relative abundance of Bacteroidetes was significantly positively related to nutrient factors, significantly negatively correlated with SP $(\mathrm{P}<0.05)$. The relative abundance of Chloroflexi was significantly positively related to PPP and SP $(\mathrm{P}<0.05)$, and negatively related to nutrient factors $(\mathrm{P}<0.05)$. Bacterial community has always been recognized as a sensitive sensor towards environmental changes, making it possible to use specific bacteria as monitoring bioindicators of pollution risks of urban river sediments $[18,36]$. However, bacterial community in freshwater sediments are often very similar at the phylum level [37]. It is hence the less abundant bacteria that may act as distinctive bioindicators for metabolic processes [38-40]. Among the less abundant phyla, only the relative abundance of Firmicutes was significantly $(\mathrm{P}<0.05)$ positively correlated with the nutrient factors, showing positive response to the pollution gradient. Besides, the relative abundance of Firmicutes showed

\section{b)}

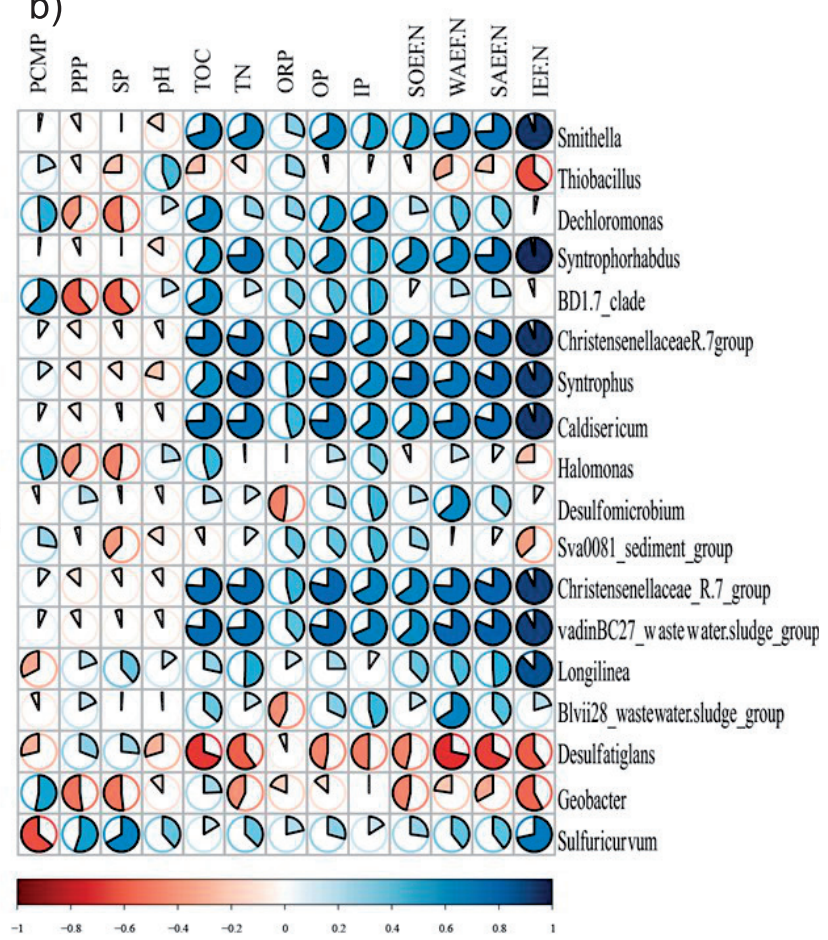

Fig. 5. Correlation analysis between bacterial community (phyla (a); genera (b)) and environmental factors. 
obvious spatial differences (Fig. 3). Thus, Firmicutes might act as the potential bioindicator for pollution risks in sediments.

At the genera level (Fig. 5b), it could be seen that most bacterial populations were significantly correlated with nutrient factors $(\mathrm{P}<0.05)$, especially with IEF-N. The relative abundance of Smithella, Syntrophorhabdus, Christensenellaceae_R-7_group, Syntrophus, Caldisericum, ChristensenellaceaeR.7 group and vadinBC27_wastewater-sludge_group were weakly correlated with particle size, while significantly positively correlated with TOC, TN as well as different forms of nitrogen and phosphorus, especially with IEF-N $(\mathrm{P}<0.05)$. As the biggest value of all sampling sites (except sample 1), the relative abundance of Thiobacillus was weakly correlated with most environmental factors, while significantly negatively correlated with IEF-N $(\mathrm{P}<0.05)$. The results indicated that the IEF-N concentration could significantly influence the bacterial community structure and composition in sediments of urban river network.

The response of bacterial community to environmental factors in sediment from urban river network has not been fully studied. And the researches mainly focused on the nutrient factors. Zhang et al. [16] explored the connection between bacterial community and environmental factors in sediment from high urbanized river network. They concluded that nutrient and heavy mental were the key factors influencing the bacterial community composition. In addition to nutrient factors, this study explored the physical characteristics of sediment from urban river network as environmental factors. Discussions above concluded that particle size and IEF-N were the main factors affecting the spatial differences of bacterial community structure in sediment from urban river network. Several previous studies had indicated that particle size was one of the key factors controlling bacterial community structure in sediments [35, 41]. Anthropogenic activity can greatly change benthic features, such as particlesize distribution and sediment permeability [42], which would further affect the bacterial community in urban river sediments. This is because difference in particle texture would affect the bacterial attachment and its access to organic substrates [43-44]. Thus, the particles with particular texture could provide conditions only suitable for specific species. As the most dynamic and unsteady transferable nitrogen, IEF-N is easy to release from the river sediment to overlying water and participate in the nitrogen cycling [45-46]. It is inferred that most genera related to nitrogen cycling would be affected by IEF-N. However, the mechanism how most genera response to IEF-N requires further research. The variation of particle size and IEF-N in sediments of two distinct Groups resulted in the difference of bacterial community composition (Table 1, Fig. 3), indicating the great impact of different degree of anthropogenic activity on bacterial community in urban river sediments. As the development of urbanization, the urban river network may be formed gradually because of the deepening impact of anthropogenic activities on the urban river morphology. Particle size and IEF-N may be paid more attention to understand the bacterial community structure and composition in sediments of urban river network.

\section{Conclusions}

This study explored the response of bacterial community to environmental factors in sediment from urban river network in this area for the first time. It is demonstrated that diversity and richness indexes of bacterial community in sediments from low urbanized area was higher than that from high urbanized area. Proteobacteria, Bacteroidetes and Chloroflexi were the dominant phyla in all sampling sites in urban river network. The bacterial community in urban river network exhibited remarkable spatial differences; they could be divided into two groups, Group I (low urbanized area) and Group II (high urbanized area). In addition to conventional nutrient indicators, the physical characteristics of sediments such as particle size distribution cannot be neglected. Based on RDA analysis, particle size and IEF-N were identified as the main factors influencing the bacterial community in sediments from urban river network.

\section{Acknowledgements}

The authors acknowledge the support of the National Nature Science Foundation of China (51778410 and 51378339).

\section{Conflict of Interest}

The authors declare no conflict of interest.

\section{References}

1. LI Q., XU X., FANG Y.Y., XIAO R.Y., WANG D.H., ZHONG W.J. The temporal changes of the concentration level of typical toxic organics in the river sediments around Beijing. Frontiers of Environmental Science \& Engineering, 12 (6), 2018.

2. WANG L., ZHANG J., LI H.L., YANG H., PENG C., PENG Z.S., LU L. Shift in the microbial community composition of surface water and sediment along an urban river. Science of the Total Environment, 627, 600, 2018.

3. WANG C.H., HE R., WU Y., LURLING M., CAI H.Y., JIANG H.L., LIU X. Bioavailable phosphorus (P) reduction is less than mobile $\mathrm{P}$ immobilization in lake sediment for eutrophication control by inactivating agents. Water Research, 109, 196, 2017.

4. CAO J.X., SUN Q., ZHAO D.H., XU M.Y., SHEN Q.S., WANG D., WANG Y., DING S.M. A critical review of the appearance of black-odorous waterbodies in China and 
treatment methods. Journal of Hazardous Materials, 385, 2020.

5. GIBBONS S.M., JONES E., BEARQUIVER A., BLACKWOLF F., ROUNDSTONE W., SCOTT N., HOOKER J., MADSEN R., COLEMAN M.L., GILBERT J.A. Human and environmental impacts on river sediment microbial community. PloS one, 9 (5), e97435, 2014.

6. ALJERF L., ALMASRI N. A gateway to metal resistance: bacterial response to heavy metal toxicity in the biological environment. Annals of Science, 2 (1), 32, 2018.

7. OIKONOMOU A., FILKER S., BREINER H.W., STOECK T. Protistan diversity in a permanently stratified meromictic lake (Lake Alatsee, SW Germany). Environmental microbiology, 17 (6), 2144, 2015.

8. IBEKWE A.M., MA J., MURINDA S.E. Bacterial community composition and structure in an Urban River impacted by different pollutant sources. Science of the Total Environment, 566, 1176, 2016.

9. LI D., SHARP J.O., DREWES J.E. Influence of wastewater discharge on the metabolic potential of the microbial community in river sediments. Microbial ecology, 71 (1), 78, 2016.

10. KOCHLING T., SANZ J.L., GALDINO L., FLORENCIO L., KATO M.T. Impact of pollution on the microbial diversity of a tropical river in an urbanized region of northeastern Brazil. International microbiology, 20 (1), 11, 2017.

11. ZHANG X., GU Q., LONG X.E., LI Z.L., LIU D.X., YE D.H., HE C.Q., LIU X.Y., VAANANEN K., CHEN X.P. Anthropogenic activities drive the microbial community and its function in urban river sediment. Journal of Soils and Sediments, 16 (2), 716, 2016.

12. YANG C.M., WU Y.Q., WANG Y.L., GUO Y.H. Microbial community structure characteristics and its key driving factors in surface sediments along Nanfei River. China Environmental Science, 38 (9), 3552, 2018.

13. GREGORY K.J. The human role in changing river channels. Geomorphology, 79 (3-4), 172, 2006.

14. ROUQUETTE J.R., DALLIMER M., ARMSWORTH P.R., GASTON K.J., MALTBY L., WARREN P.H. Species turnover and geographic distance in an urban river network. Diversity and Distributions, 19 (11), 1429, 2013.

15. YU Z.J., DENG H.G., WANG D.Q., YE M.W., TAN Y.J., LI Y.J., CHEN Z.L., XU S.Y. Nitrous oxide emissions in the Shanghai river network: Implications for the effects of urban sewage and IPCC methodology. Global Change Biology, 19 (10), 2999, 2013.

16. ZHANG F., ZHANG H., YUAN Y., LIU D., ZHU C.Y., ZHENG D., LI G.H., WEI Y.Q., SUN D. Different response of bacterial community to the changes of nutrients and pollutants in sediments from an urban river network. Frontiers of Environmental Science \& Engineering, 14 (2), 41, 2020.

17. SUN M.Y., DAFFORN K.A., JOHNSTON E.L., BROWN M.V. Core sediment bacteria drive community response to anthropogenic contamination over multiple environmental gradients. Environ. Microbiol, 15 (9), 2517, 2013.

18. XIE Y.W., WANG J.Z., WU Y., REN C., SONG C., YANG J.H., YU H.X., GIESY J.P., Zhang X.W. Using in situ bacterial community to monitor contaminants in river sediments. Environmental Pollution, 212, 348, 2016.

19. Standardization Administration of China (SAC). Water quality-Determination of total organic carbon-Combustion oxidation nondispersive infrared absorption method.; Standards press of china: Beijing, China, 2009.
20. Standardization Administration of China (SAC). Soil quality- Determination of total nitrogen- Modified Kjeldahl method.; Standards press of china: Beijing, China, 2014.

21. WANG S. Sediment-Water Interface Process of LakesNitrogen and Phosphorus Biogeochemistry, first ed.; Science Press: Beijing, China, 2013.

22. ZHANG M.Z., WU Z.J., SUN Q.Y., DING Y.X., DING Z.W., SUN L.L. The spatial and seasonal variations of bacterial community structure and influencing factors in river sediments. Journal of environmental management, 248, 2019.

23. NIU L.H., LI Y., WANG P.F., ZHANG W.L., WANG C., WANG Q. Understanding the linkage between elevation and the activated-sludge bacterial community along a 3,600-meter elevation gradient in China. Applied and environmental microbiology, 81 (19), 6567, 2015.

24. LIU S., REN H.X., SHEN L.D., LOU L.P., TAN G.M., ZHENG P., HU B.L. pH levels drive bacterial community structure in sediments of the Qiantang River as determined by 454 pyrosequencing. Frontiers in microbiology, 6, 285, 2015.

25. ZHANG J.X., YANG Y.Y., ZHAO L., LI Y.Z., XIE S.G., LIU Y. Distribution of sediment bacterial and archaeal community in plateau freshwater lakes. Applied Microbiology and Biotechnology, 99 (7), 3291, 2015.

26. MEZITI A., TSEMENTZI D., KORMAS K.A., KARAYANNI H., KONSTANTINIDIS K.T. Anthropogenic effects on bacterial diversity and function along a river-to-estuary gradient in Northwest Greece revealed by metagenomics. Environmental Microbiology, 18 (12), 4640, 2016.

27. YE B.X., ZHANG Z.H., MAO T. Pollution sources identification of polycyclic aromatic hydrocarbons of soils in Tianjin area, China. Chemosphere, 64 (4), 525, 2006.

28. YAMADA T., IMACHI H., OHASHI A., HARADA H., HANADA S., KAMAGATA Y., SEKIGUCHI Y. Bellilinea caldifistulae gen. nov. sp. nov. and Longilinea arvoryzae gen. nov. sp. nov. strictly anaerobic, filamentous bacteria of the phylum Chloroflexi isolated from methanogenic propionate-degrading consortia. International journal of systematic and evolutionary microbiology, 57 (10), 2299, 2007.

29. SHENG P., YU Y.Z., ZHANG G.H., HUANG J.L., HE L., DING J.N. Bacterial diversity and distribution in seven different estuarine sediments of Poyang Lake, China. Environmental Earth Sciences, 75 (6), 479, 2016.

30. XIONG W., XIE P., WANG S.R., NIU Y., YANG X., CHEN W.J. Sources of organic matter affect depth-related microbial community composition in sediments of Lake Erhai, Southwest China. Journal of Limnology, 74 (2), 310, 2015.

31. ALTMANN D., STIEF P., AMANN R., DE BEER D., SCHRAMM A. In situ distribution and activity of nitrifying bacteria in freshwater sediment. Environmental Microbiology, 5 (9), 798, 2003.

32. YU J.H., FAN C.X., ZHONG J.C., ZHANG Y.L., WANG C.H., ZHANG L. Evaluation of in situ simulated dredging to reduce internal nitrogen flux across the sediment-water interface in Lake Taihu, China. Environmental Pollution, 214, 866, 2016.

33. KAESTLI M., SKILLINGTON A., KENNEDY K., MAJID M., WILLIAMS D., MCGUINNESS K., MUNKSGAARD N., GIBB K. Spatial and temporal microbial patterns in a tropical macrotidal estuary subject to urbanized. Frontiers in Microbiology, 8, 2017. 
34. FAN X.F., XING P. The vertical distribution of sediment archaeal community in the "black bloom" disturbing Zhushan Bay of Lake Taihu. Archaea, 2016, 2016.

35. WANG L.P., LIU L.S., ZHENG B.H., ZHU Y.Z., WANG X. Analysis of the bacterial community in the two typical intertidal sediments of Bohai Bay, China by pyrosequencing. Marine Pollution Bulletin, 72 (1), 181, 2013.

36. YU H.M., ZHAO Y., ZHANG C., WEI D., WU J.Q., ZHAO X.Y., HAO J.K., WEI Z.M. Driving effects of minerals on humic acid formation during chicken manure composting: Emphasis on the carrier role of bacterial community. Bioresource Technology, 294, 122239, 2019.

37. JI Y., ANGEL R., KLOSE M., CLAUS P., MAROTTA H., PINHO L., ENRICH-PRAST A., CONRAD R. Structure and function of methanogenic microbial community in sediments of Amazonian lakes with different water types. Environmental Microbiology, 18 (12), 5082, 2016.

38. LIANG Z.W., SIEGERT M., FANG W.W., SUN Y., JIANG F., LU H., CHEN G.H., WANG S.Q. Blackening and odorization of urban rivers: a bio-geochemical process. FEMS microbiology ecology, 94 (3), 2018.

39. DENG Y., ZHANG P., QIN Y.J., TU Q.C., YANG Y.F., HE Z.L., SCHADT C.W., ZHOU J.Z. Network succession reveals the importance of competition in response to emulsified vegetable oil amendment for uranium bioremediation. Environmental Microbiology, 18 (1), 205, 2016.

40. YANG J.J., LI G.H., QIAN Y., YANG Y.F., ZHANG F. Microbial functional gene patterns related to soil greenhouse gas emissions in oil contaminated areas. Science of the Total Environment, 628-629, 94, 2018.

41. ZHENG B.H., WANG L.P., LIU L.S. Bacterial community structure and its regulating factors in the intertidal sediment along the Liaodong Bay of Bohai Sea, China. Microbiological research, 169 (7-8), 585, 2014.

42. MORING J.R. Decrease in stream gravel permeability after clear-cut logging: an indication of intragravel conditions for developing salmonid eggs and alevins. Hydrobiologia, 88 (3), 295, 1982.

43. JICKELL T.D., RAE J.E. Biogeochemistry of intertidal sediments.; Cambridge University Press: Cambridge, England, pp. 1-15, 1997.

44. RUSCH A., HUETTEL M., REIMERS C.E., TAGHON G.L., FULLER C.M. Activity and distribution of bacterial populations in Middle Atlantic Bight shelf sands. FEMS Microbiology Ecology, 44 (1), 89, 2003.

45. ZHANG B., CHEN Y.P., FANG F., LI Z., GUO J.S., WANG $Z$. Nitrogen forms and their distribution characteristics in the soils of water-level- luctuationg zone in the central Three Gorges Reservoir. Acta Scientiae Circumstantiae, 32 (5), 1126, 2012.

46. LIU J.J., ZHANG S., YANG Z.Y., HE L.P., ZHOU N., ZHANG Q.R. Effect of drought and subsequent re-wetting cycles on transferable nitrogen and its form distribution in the sediment of water level fluctuating zone in the tributary of Three Gorge reservoir areas. Environmental Science, 36 (7), 2459, 2015 